Gut, 1989, 30, 1123-1128

\title{
Subclasses of antibodies to hepatitis B core antigen in chronic HBV infection: changes during treatment with alpha interferons and predictors of response
}

\author{
G CHEN, P KARAYIANNIS, M J McGARVEY, A M L LEVER, \\ J A MCDONALD, L J SCULLY, S KANATAKIS, AND H C THOMAS
}

From the Department of Medicine, St Mary's Hospital Medical School, Imperial College of Science, Technology and Medicine, London

SUMMARY Response to interferon therapy in chronic hepatitis B virus (HBV) carriers is preceded by the appearance of IgM class anti-HBc (antibody to hepatitis B core antigen). The temporal relationship and magnitude of the $\mathrm{IgM}$ anti-HBc response is variable suggesting that the antibody is not directly involved in hepatocyte lysis, but is merely a marker of a changed state of immunity to the nucleocapsid proteins, induced by interferon. IgG 1, 2,3, and 4 class anti-HBc did not change during therapy, but IgG 3 anti-HBc was significantly lower in responders than non-responders. IgG antiHBc of all subclasses was absent in two Chinese HBV carriers. Lower than normal titres of anti-HBc $(p<0 \cdot 001)$ were detected in human immunodeficiency virus antibody positive (anti-HIV) HBV carriers. These data indicate the presence of altered immunity to the nucleocapsid antigens in these two types of chronic HBV carrier that are known to respond poorly to antiviral therapy.

IgM antibody plays an important role in immune lysis of infected cells during some acute viral infections, and may also have a role in acute viral hepatitis. ${ }^{12}$ IgM anti-HBc is the first antibody appearing soon after HBV infection. ${ }^{3}$ In chronic HBV infection, IgM anti-HBc may be persistently present in lower titres. ${ }^{+}$

IgG anti-HBc is also present in both acute and chronic HBV infection and it has been suggested that the binding of non-complement fixing IgG to $\mathrm{HBcAg}$ (hepatitis B core antigen) displayed on infected hepatocytes may down modulate T-cell lysis of infected cells. ${ }^{5}$ Consistent with this hypothesis is the observation that chimpanzees injected with large quantities of monoclonal antibody to the nucleocapsid proteins at the time of HBV challenge, develop protracted infection. ${ }^{\circ}$ Moreover, cytotoxic T-cells sensitised to both $\mathrm{HBeAg}$ and $\mathrm{HBcAg}$ displayed in hepatocyte membranes have been demonstrated during acute and chronic HBV infection, ${ }^{7}$ and

Address for correspondence: Professor H C Thomas, Department of Medicine, St Mary's Hospital Medical School, South Wharf Road, London W2 1NY.

Accepted for publication 19 December 1988.
MHC class I antigen expression on hepatocytes has been shown to be enhanced during acute infection. ${ }^{8}$ Thus the balance of antibody and interferon modulation of T-cell lysis of infected cells may determine the efficiency of clearance of the virus.

In this study the sera of HBV carriers undergoing treatment with interferon were examined for changes in titre of total anti-HBc, as well as IgM and IgG subclass distribution. Some of these patients were anti-HIV positive. The data were analysed to try to identify factors which might predict a beneficial response to interferon therapy.

\section{Methods}

PATIENTS

Thirty seven consecutive chronic HBV carriers who attended the hepatitis clinic from August 1983 until September 1985 for antiviral treatment with lymphoblastoid interferon were investigated. ${ }^{4}$ Their mean age was $36.9(3.8)$ years and the duration of their chronic infection was greater than $33.9(6.4)$ months. All of them were HBsAg, $\mathrm{HBeAg}$, and HBV-DNA 
positive in serum for at least six months before the start of therapy with interferon. Their mean AST (aspartate transaminase) was 109 (21 SEM) IU/l. All except one patient, had a liver biopsy within three months before the start of treatment and all specimens revealed histologic evidence of chronic hepatitis. Twenty six had chronic active hepatitis $(\mathrm{CAH})$, one chronic persistent hepatitis $(\mathrm{CPH})$, three cirrhosis, and six minimal disease. Only four patients in this trial were anti-HIV positive. In this group of patients both total and IgM anti-HBc determinations were carried out and these were correlated to subsequent seroconversion after interferon treatment. The titres of IgM and/or total anti$\mathrm{HBc}$ given represent the highest ones recorded during the test period.

In order to study more fully the effect of HIV immunosuppression on HBV carriers, sera from patients recruited into another trial were tested for total anti-HBc before start of treatment. ${ }^{10}$ From this group of patients 21 of $55 \mathrm{HBV}$ chronic carriers were positive for anti-HIV. All of them were $\mathrm{HBsAg}$, $\mathrm{HBeAg}$, and HBV-DNA positive in serum. Their mean age was 34.7 (range 18-65) and they had a mean AST of 69 (22) IU/l. On liver biopsy $33 \mathrm{had}$ $\mathrm{CAH}$, seven $\mathrm{CPH}$, three chronic lobular hepatitis $(\mathrm{CLH})$, and 12 minimal disease.

No evidence of HDV (hepatitis delta virus) was found in either the serum or the liver of patients investigated in the two studies.

\section{TREATMENT}

Patients were treated with $10 \times 10^{h}$ units $/ \mathrm{m}^{2}$ of lymphoblastoid interferon (Wellferon, Wellcome Biotechnology) intramuscularly, three times weekly for 12 or 24 weeks. Patients were seen weekly during treatment, and for four weeks after completion of therapy and then at monthly intervals for a further year. Blood samples were taken at each visit and serum was stored at $-20^{\circ} \mathrm{C}$.

\section{SEROLOGICAL INVESTIGATIONS}

Serum specimens were tested for $\mathrm{HBsAg}$ by a radioimmunoassay (RIA) utilising murine monoclonal antibodies, ${ }^{11} \mathrm{HBe} \mathrm{Ag} / \mathrm{anti}-\mathrm{HBe}$, anti-HBs, and anti-HD by commercial RIA (Abbott Laboratories, North Chicago, Ill). Serum HBV-DNA was detected by molecular hybridsation using a ${ }^{32} \mathrm{P}$-labelled HBVDNA probe. ${ }^{12}$ Anti-HIV was measured by ELISA (Wellcozyme, Wellcome Diagnostics, Dartford, England). Total anti-HBc was measured by a competitive inhibition ELISA method utilising horseradish peroxidase labelled monoclonal IgG anti-HBc ${ }^{14}$ as tracer. Samples were log diluted before testing. The highest dilution still reactive for anti$\mathrm{HBc}$ was taken as the titre. IgM anti-HBc was measured by an ELISA system as described previously. ${ }^{15}$ it $\operatorname{IgG} 1,2,3$, and 4 anti-HBc antibodies were measured by an ELISA system similar to that for $\operatorname{IgM}$ anti-HBc, but monoclonal anti-IgG 1, 2, 3, and 4 were used as the capture phase respectively (Serotec, UK). Sera were again log diluted and then tested. Sera negative in the total anti-HBc assay were negative also in the assay for the isotypes of $\mathrm{IgG}$ anti$\mathrm{HBc}$. The highest dilution with a $\mathrm{P} / \mathrm{N}$ (positive/ negative) ratio of $>2 \cdot 1$ reactive for anti- $\mathrm{HBc}$ was taken as the titre of the relevant subclass IgG anti$\mathrm{HBc}$.

\section{Results}

Ig M-ANTI-HBc

Thirty of thirty seven $(81 \%)$ interferon treated patients with chronic HBV infection were positive for IgM anti-HBc during treatment: six of these were positive before treatment and the remaining 24 became positive one to three weeks after starting treatment. This increased rate of IgM anti-HBc positivity after treatment was highly significant $(\mathrm{p}<0 \cdot 001$, Table 1$)$.

Three patterns of IgM anti-HBc response were found. The first was of persistently raised titres of $\operatorname{IgM}$ anti-HBc during treatment and was noted in 13 patients. Three of these patients were IgM anti-HBc positive before start of treatment. This group of patients was subdivided into two further subgroups depending on the titre of IgM anti-HBc: those with high titres $(>1: 8000$, seven cases) and those with low titres $(\leqslant 1: 8000$, six cases). The second group (10 cases), which included the remaining three patients who were positive for IgM anti-HBc before treatment, exhibited fluctuating titres of IgM anti-HBc during treatment. This group was also subdivided into those with high titre (four cases) and low titre (six cases) of IgM anti-HBc. The third group (seven cases) demonstrated a transient presence of IgM anti$\mathrm{HBc}$, with only one or two samples being positive at low titre. The remaining seven cases were negative

Table 1 Number of patients positive for IgM anti- $\mathrm{HBC}$ before, and number becoming positive during interferon treatment

\begin{tabular}{|c|c|c|c|c|}
\hline & \multicolumn{3}{|c|}{$\operatorname{Ig} M$ anti-HBc} & \multirow[b]{3}{*}{ Total } \\
\hline & \multirow{2}{*}{$\begin{array}{l}\text { Before } \\
\text { treatment }\end{array}$} & \multicolumn{2}{|c|}{ During treatment } & \\
\hline & & l-2 weeks & $>3$ weeks & \\
\hline Positive (n) & $6 / 37$ & $19 / 37$ & $5 / 37$ & $30 / 37$ \\
\hline Positive (\%) & $16 \cdot 1$ & $51 \cdot 4$ & $13 \cdot 5$ & $81 \cdot 0$ \\
\hline
\end{tabular}

$\chi^{2}=15 \cdot 93 ; \mathrm{p}<0 \cdot 001$. 
Table 2 Relationship between presence and absence of $\operatorname{IgM}$ anti-HBc, titre of $\operatorname{IgM}$ anti-HBc and number of patients seroconverting after treatment with alpha interferon

\begin{tabular}{|c|c|c|c|c|c|c|}
\hline \multirow[b]{2}{*}{$\begin{array}{l}\text { IgM anti-HBc} \\
\text { response }\end{array}$} & \multirow[b]{2}{*}{ Titre } & \multirow[b]{2}{*}{$\begin{array}{l}\text { Patients } \\
(n)\end{array}$} & \multirow[b]{2}{*}{$\begin{array}{l}\text { Seroconverting } \\
(n)\end{array}$} & \multirow[b]{2}{*}{ p value } & \multicolumn{2}{|l|}{ Number losing } \\
\hline & & & & & $H B s A g / H B e A g$ & HBeAg alone \\
\hline \multirow[t]{3}{*}{ Persistent } & all & 13 & 10 & $<0.01^{*},=0.001^{\dagger}$ & 7 & 3 \\
\hline & $>1: 8000$ & 7 & 7 & $b_{-0.05+}$ & 4 & 3 \\
\hline & $\leqslant 1: 8000$ & 6 & 3 & \}$=(0 \cdot 0.57$ & 3 & 0 \\
\hline \multirow[t]{3}{*}{ Fluctuating } & all & 10 & 8 & $<0.01^{*},=0.001 \dagger$ & 1 & 7 \\
\hline & $>1: 8000$ & 4 & 4 & & 1 & 3 \\
\hline & $\leqslant 1: 8000$ & 6 & 4 & NSt: & () & 4 \\
\hline Transient & $\leqslant 1: 8000$ & 7 & 1 & & () & 1 \\
\hline None & 0 & 7 & 0 & & 0 & 0 \\
\hline Total & & 37 & 19 & & 8 & 11 \\
\hline
\end{tabular}

*From $\chi^{2}$ tests, comparing the number of patients seroconverting to those not seroconverting in the relevant group, with those in the group with transient IgM anti-HBc; †From $\chi^{2}$ tests, comparing the number of patients seroconverting to those not seroconverting in the relevant group, with those in whom no IgM anti-HBc was detected: $\$$ From $\chi^{2}$ tests, comparing the number of patients seroconverting to those not seroconverting separated according to the titre of IgM anti-HBc. NS, not significant.

for IgM anti-HBc throughout. The relationship of these patterns of IgM anti-HBc to response to interferon are shown in Table 2 and an example of seroconversion in Figure 1.

Table 3 correlates the various IgM anti-HBc responses after interferon treatment to pretreatment HBV-DNA and AST levels. There was no significant

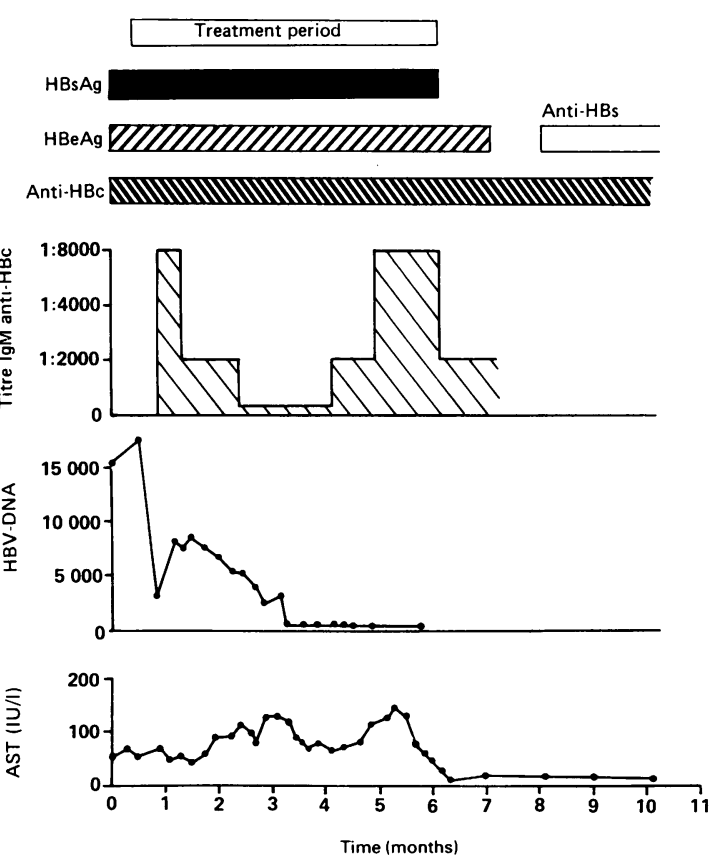

Fig. 1 AST level, viral markers and $H B V-D N A$ (densitometric units) in relation to IgM anti-HBc in a patient treated with interferon for 24 weeks. difference in HBV-DNA levels when comparing these between groups. AST levels were lower in the groups without or with transient IgM anti-HBc responses but the differences did not reach statistical significance. There were only four anti-HIV positive patients (one in each group), three of which were non-responders.

TOTAL ANTI-HBC

All serum samples tested from the interferon treated patients (except those from two) were positive for total anti-HBc. Titres were greater than 1:100. No change in the titre of total anti- $\mathrm{HBc}$ was observed in any of the patients before or during treatment with interferon. The increases in $\mathrm{IgM}$ anti-HBc titres described were not evident from the total anti-HBc results.

There were four Chinese patients in this study. Two of these were negative for total anti-HBc in sera taken from the whole period of investigation. Similar results were obtained for IgM anti-HBc and tests for the four IgG subclasses of anti-HBc.

Table 3 IgM anti-HBc response in relation to other prognostic factors that may determine outcome of response to interferon treatment

\begin{tabular}{llll}
\hline $\begin{array}{l}\text { IgManti-HBc } \\
\text { response }\end{array}$ & $\begin{array}{l}\text { HBV-DNA } \\
\text { (densitometric units) }\end{array}$ & $\begin{array}{l}\text { AST } \\
(I U / l)\end{array}$ & $\begin{array}{l}\text { HIV } \\
\text { Status }\end{array}$ \\
\hline Persistent & $26552(3424)$ & $123(46 \cdot 7)$ & $1 / 13$ \\
Fluctuating & $20281(2811)$ & $151(64 \cdot 5)$ & $1 * / 10$ \\
Transient & $26451(4264)$ & $97(31 \cdot 5)$ & $1 / 7$ \\
None & $24190(2135)$ & $73(24 \cdot 2)$ & $1 / 7$ \\
\hline
\end{tabular}

*Lost $\mathrm{HBe} \mathrm{Ag}$ but was still anti-HBe negative at the end of follow up. Data are mean (SEM). 
Table 4 Titres of total anti-HBc in anti-HIV positive and negative $H B V$ chronic carriers, before start of treatment with recombinant alpha $2 A$ interferon

\begin{tabular}{llllllll}
\hline \multirow{2}{*}{$\begin{array}{l}\text { Anti-HIV } \\
\text { status }\end{array}$} & \multicolumn{7}{l}{ Number with anti-HBc titre of: } \\
\cline { 2 - 7 } & 0 & $10^{\prime \prime}$ & $10^{\prime}$ & $10^{\circ}$ & $10^{\circ}$ & $10^{4}$ & Total \\
\hline Positive & 4 & 4 & 0 & 3 & 3 & 7 & 21 \\
Negative & 0 & 0 & 0 & 6 & 9 & 19 & 34 \\
\hline
\end{tabular}

$\chi^{3}=15 \cdot 29 ; \mathrm{p}<0 \cdot(0) 1$, comparing those with high $\left(\leqslant 10^{\prime}\right)$ and low titre anti-HBc.

Another group of patients with chronic HBV infection entering into a trial of recombinant alpha interferon (55 cases) were studied. ${ }^{11}$ These were subdivided into two groups, anti-HIV positive (21) and negative (34). The results of total anti- $\mathrm{HBc}$ are shown in Table 4. Four patients were negative and four others were weakly positive for total anti-HBc in the anti-HIV positive group. The mean titre of total anti-HBc in this group was lower than that of the antiHIV negative group $(\mathrm{p}<0.001)$.

Of the 37 treated patients who were initially tested, four were anti-HIV positive. In this small group of anti-HIV positive patients the anti-HBc titres were $10^{4}$ in one, $10^{3}$ in two, and $10^{2}$ in the remaining patient.

\section{IgG ANTI-HBC SUBCLASSES}

IgG anti-HBc subclasses were studied in sera from seven patients who seroconverted (lost both $\mathrm{HBsAg}$ and $\mathrm{HBeAg}$ ) and 12 without seroconversion to determine whether alterations in the titre of these subclasses were related to the outcome of therapy. These patients were all male, they were anti-HIV negative and all had CAH. Sera before, during, and after treatment with interferon were tested. No obvious changes either in titre or in relative proportions of the IgG anti-HBc subclasses could be found during the course of therapy in the two groups (Fig. 2). All of the sera tested from these patients were positive for the four IgG anti-HBc subclasses. IgG 3 anti-HBc was the dominant subclass in the nonresponder group $(p<0 \cdot 01)$ but did not change during therapy. By contrast in the responding patients IgG 3 anti-HBc was similar in titre to the other IgG subclasses, and once again did not change during therapy. Responders had higher AST levels $(\mathrm{p}<0.01)$, slightly lower HBV-DNA levels and a higher incidence of a past history of acute hepatitis $(\mathrm{p}<0.05)$.

\section{Discussion}

During acute type B hepatitis the level of serum

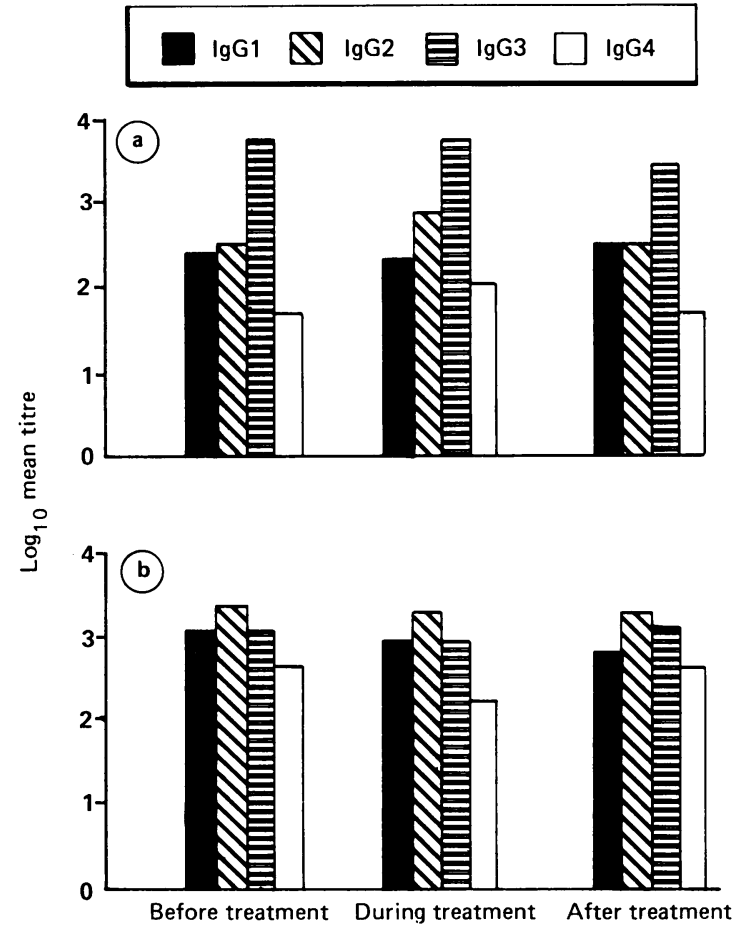

Fig. 2 Comparison of $\lg G$ anti-HBc subclasses before, during, and after treatment with interferon. (a) Nonseroconversion and (b) seroconversion groups.

HBV-DNA falls as the titre of IgM anti-HBc increases. ${ }^{16}$ HBV-DNA levels decrease in patients with chronic HBV infection on interferon therapy ${ }^{111} 17$ and as shown in this study, in seroconverters, this event is also coincident with the appearance of or a rise in the titre of, IgM anti-HBc. Interferon also enhances MHC class I antigen expression on liver cells ${ }^{x}$ and it is suggested that this allows the nucleocapsid proteins to be seen by cytotoxic T-cells ${ }^{b}$ and lysis of the infected cells follows. Whether the cellmediated response alone, or type II and III complement dependent mechanisms ${ }^{1 \mathrm{x}}$ are also responsible for the lysis of infected cells, is not clear.

The incidence of IgM anti-HBc in $\mathrm{HBs} A g$ positive chronic liver disease has varied depending on the group of patients studied and the assays used. ${ }^{14}$ In general IgM anti-HBc titres in chronic carriers are considerably lower than in acute hepatitis, ${ }^{1521}$ they are more often found in patients with $\mathrm{CAH}(30-$ $43 \%)^{2122}$ than those with CPH $(11 \%)^{21}$ or minimal disease $(0-6 \%)^{2122}$ : there is a strong relationship with inflammatory activity. ${ }^{1422}$ In this study $81 \%$ of the patients on interferon became positive for IgM anti$\mathrm{HBc}$ and although there existed a close predictive 
relationship between $\operatorname{IgM}$ anti-HBc and seroconversion, the time of the seroconversions did not relate to the time of appearance, duration or titre of IgM anti-HBc. This suggests that the IgM anti-HBc response may not be directly related to clearance of infected cells but merely an indication of induction, by interferon, of the immune response to nucleocapsid proteins. These data suggest that the immunomodulatory effects of interferon may play an important role in eradicating the chronic infection.

In this study we failed to find any correlation between IgG anti-HBc levels and seroconversion on treatment with interferon. $\operatorname{IgG} 1,2,3$, and 4 subclasses of anti-HBc were constant in titre and in relative proportions. Trevisan et $l^{2.3}$ reported that the eluted immunoglobulins from membranes of HBV infected hepatocytes were restricted to IgG 1 and IgG 3 subclasses, and these showed a specificity for $\mathrm{HBcAg}$. Our data show that there is no lack of IgG 2 and IgG 4 anti-HBc in serum and the reason for these antibodies not being detected in the membrane eluate is unclear. The titre of IgG 3 anti-HBc was significantly higher than the other subclasses $(p<0 \cdot 1)$ in the group not seroconverting during therapy. IgG 3 antibody appears to relate to the duration of infection, ${ }^{24}$ and therefore the higher titre of IgG 3 anti-HBc in non-responders may merely reflect the duration of $\mathrm{HBV}$ infection.

Two Chinese patients were negative for anti-HBc. Low anti-HBc titres are more frequent in patients with liver cirrhosis, but rare in healthy carriers and patients with $\mathrm{CAH}$ or $\mathrm{CPH}$. Both of our patients with absent anti-HBc responses were healthy carriers with normal AST and liver histology. This total absence of anti-HBc in $\mathrm{HBsAg} / \mathrm{HBeAg}$ positive patients suggests a state of tolerance to $\mathrm{HBcAg}$. Whether this has arisen because of infection in utero or is related to genetic factors is unclear. These patients did not produce IgM anti- $\mathrm{HBc}$ during therapy and did not respond.

Low titres or absence of anti-HBc were also found in eight patients with anti-HIV antibody, and only a few showed an IgM anti-HBc response after starting interferon treatment. This suggests a deficiency in specific humoral immune responses even though immunoglobulins are increased..$^{25}$ The majority of the eight patients without any anti-HBc or low levels of this antibody had more clinical features of HIV infection (four had generalised lymphadenopathy, one had Pneumocystis carinii pneumonia and one other Kaposi's sarcoma) than the 13 patients who were anti-HIV positive and had normal levels of anti$\mathrm{HBc}$. Thus in HIV infected individuals, a falling anti-HBc titre may be of prognostic value and further prospective studies will be needed to address this issue.
M McGarvey and A M L Lever are supported by the Welløome Trust.

\section{References}

1 Drew WL. Classification and general concepts. In: Drew WL, ed. Viral infections. A Clinical approach. Philadelphia: FA Davis, 1976: 12-22.

2 Notkins AL, Koprowski H. How the immune response to a virus can cause disease. In: Burnet FM, ed. Immunology. San Francisco: WH Frecman, 1976: 23241.

3 Angarano G, Monno L, Santantonio TA, et al. New principle for the simultancous detection of total and immunoglobulin $\mathrm{M}$ antibodies applied to the measurement of antibody to hepatitis B core antigen. J Clin Microbiol 1984; 19: 805-10.

4 Sjogren M, Hoofnagle JH. Immunoglobulin M antibody to hepatitis B core antigen in patients with chronic type B hepatitis. Gastroenterology 1985; 89: 252-8.

5 Naumov NV, Mondelli M, Alexander GJM, Tedder RS, Eddleston ALW, Williams R. Relationship between expression of hepatitis $\mathrm{B}$ virus antigen in isolated hepatocytes and autologous lymphocyte cytotoxicity in patients with chronic hepatitis $B$ virus infection. Hepatology 1984; 4: 63-8.

6 Pignatelli M, Waters J, Lever AML, Iwarson S, Gerety $\mathrm{S}$, Thomas HC. Cytotoxic T cell responses to nucleocapsid proteins of $\mathrm{HBV}$ in chronic hepatitis: evidence that antibody modulation may cause protracted infection. J Hepatol 1987; 4: 15-21.

7 Mondelli M, Mieli-Vergani G, Alberti A, et al. Specificity of $\mathrm{T}$ lymphocyte cytotoxicity to autologous hepatocytes in chronic hepatitis $B$ virus infection: evidence that $T$ cells are directed against HBV core antigen expressed on hepatocytes. J Immunol 1982; 129: 2773-8.

8 Pignatelli M, Waters J, Brown D, et al. HLA class I antigens on the hepatocyte membrane during recovery from acute hepatitis $B$ virus infection and during interferon therapy in chronic hepatitis B virus infection. Hepatology 1986; 6: 349-53.

9 Scully LJ, Shein R, Karayiannis P, McDonald JA. Thomas HC. Lymphoblastoid interferon therapy of chronic HBV infection: A comparison of 12 versus 24 wecks of thrice weekly treatment. J Hepatol 1987; 5: 51-8.

10 McDonald JA, Caruso L, Karayiannis $\mathrm{P}$, et al. Diminished responsiveness of male homosexual chronic hepatitis B virus carriers with HTLV-III antibodies to recombinant - interferon. Hepatology 1987; 7: 719-23.

11 Goodall AH, Meek FL, Waters JA, Miescher GC, Janossy G, Thomas HC. A rapid one-step radiometric assay for hepatitis B surface antigen utilising monoclonal antibodies. J Immunol Meth 1982; 52: 167-74.

12 Weller IVD, Fowler MJF, Monjardino J, Thomas HC. The detection of HBV-DNA in the serum by molecular hybridisation: A more sensitive method for detection of complete HBV particles. J Med Virol 1982; 9: 273-80.

13 Karayiannis P, Fowler MJF, Lok ASF, Greenficld C. 
Monjardino J, Thomas HC. Detection of serum HBVDNA by molecular hybridisation in correlation with $\mathrm{HBeAg} /$ anti-HBe status, racial origin, liver histology and hepatocellular carcinoma. J Hepatol 1985; 1: 99106.

14 Waters JA, Jowett TP, Thomas HC. Identification of a dominant immunogenic epitope of the nucleocapsid (HBc) of the hepatitis B virus. J Med Virol 1986; 19: 7986.

15 Greenfield C, Karayiannis P, Wankya BM, et al. Aetiology of acute sporadic hepatitis in adults in Keyna. J Med Virol 1981; 14: 357-62.

16 Lok ASF, Karayiannis P, Jowett TP, et al. Studies of HBV replication during acute hepatitis followed by recovery and acute hepatitis progressing to chronic disease. J Hepatol 1985; 1: 671-9.

17 Lok ASF, Novick DM, Karayiannis P, Dunk AA, Sherlock S, Thomas HC. A randomised study of the effects of adenine arabinoride 5'-monophosphate and lymphoblastoid interferon on hepatitis B virus replication. Hepatology 1985; 5: 1132-8.

18 Potter BJ, Elias E, Thomas HC, Sherlock S. Complement metabolism in chronic liver disease: Catabolism of $\mathrm{Clq}$ in chronic active liver disease and primary biliary cirrhosis. Gastroenterology 1980; 78: 1034-40.

19 Feinman SV, Overby LR, Berris B, Chau K, Schable CA. Maynard JE. The significance of IgM antibodies to hepatitis B core antigen in hepatitis B carricrs and hepatitis B-associated chronic liver disease. Hepatology 1982; 2: 795-9.

20 Kryger P, Mathiesen LR, Aldershville J, et al. Presence and meaning of anti-HBc IgM as determined by ELISA in patients with acute type B hepatitis and healthy HBsAg carriers. Hepatology 1981; 1: 233-7.

21 Surrenti C, Ambu S, Patussi V, et al. Diagnostic significance of anti-HBc IgM (RIA) in healthy HBsAg carriers and in chronic hepatitis B. J Med Virol 1986; 18: 229-34.

22 Banninger P, Altorfer J, Frosner GG, et al. Prevalence and significance of anti-HBc IgM in acute and chronic hepatitis B and in blood donors. Hepatology 1983; 3: $337-42$.

23 Trevisan A, Realdi G, Alberti A, Ongaro G, Pornaro E, Meliconi R. Core antigen-specific immunoglobulin G bound to the liver cell membrane in chronic hepatitis $\mathrm{B}$. Gastroenterology 1982; 82: 218-22.

24 Beck OE. Distribution of virus antibody activity among human IgG Subclasses. Clin Exp Immunol 1981; 43: 626-32.

25 Nicholson JK, McDongal JS, Jaffe HW. Exposure to human T-lymphotrophic virus type III/Lymphadenopathy-associated virus and immunologic abnormalitics in asymptomatic homosexual men. Ann Intern Med 1985; 103: 37-42. 